\title{
Caspases in cell survival, proliferation and differentiation
}

\author{
M Lamkanfi ${ }^{1,2}$, N Festjens $^{1}$, W Declercq ${ }^{1}$, T Vanden Berghe $^{1}$ and P Vandenabeele ${ }^{*, 1}$
}

Caspases, a family of evolutionarily, conserved cysteinyl proteases, mediate both apoptosis and inflammation through aspartate-specific cleavage of a wide number of cellular substrates. Most substrates of apoptotic caspases have been conotated with cellular dismantling, while inflammatory caspases mediate the proteolytic activation of inflammatory cytokines. Through detailed functional analysis of conditional caspase-deficient mice or derived cells, caspase biology has been extended to cellular responses such as cell differentiation, proliferation and NF- $\kappa$ B activation. Here, we discuss recent data indicating that nonapoptotic functions of caspases involve proteolysis exerted by their catalytic domains as well as non-proteolytic functions exerted by their prodomains. Homotypic oligomerization motifs in the latter mediate the recruitment of adaptors and effectors that modulate NF- $\kappa \mathrm{B}$ activation. The non-apoptotic functions of caspases suggest that they may become activated independently of - or without - inducing an apoptotic cascade. Moreover, the existence of non-catalytic caspase-like molecules such as human caspase-12, c-FLIP and CARD-only proteins further supports the non-proteolytic functions of caspases in the regulation of cell survival, proliferation, differentiation and inflammation.

Cell Death and Differentiation (2007) 14, 44-55. doi:10.1038/sj.cdd.4402047; published online 20 October 2006

Caspases are an evolutionarily conserved family of aspartatespecific cystein-dependent proteases with central functions in apoptotic and inflammatory signalling pathways. ${ }^{1}$ Certain caspases have large prodomains that contain related homotypic oligomerization motifs such as the caspase recruitment domain (CARD, caspase-1, -2, -4, -5, -9, -11, -12) and the death effector domain (DED, caspase-8 and -10). Proximityinduced caspase auto-activation occurs in large multimeric complexes that consist of a platform protein that specifically recruits large prodomain caspases, either directly or by means of adaptors. ${ }^{2}$ Well-studied caspase complexes include the apoptosome, ${ }^{3}$ the death inducing signalling complex (DISC), ${ }^{4,5}$ the PIDDosome ${ }^{6}$ and the caspase-1-containing inflammasomes. ${ }^{7}$ The short prodomain caspases (caspase-3, $-6,-7,-14)$ are activated by proteolytic maturation by large prodomain caspases or other proteases. The final outcome of these proteolytic cascades is the specific cleavage of a wide variety of substrates that are implicated in apoptosis.

The observation of caspase activity and the identification of caspase substrates in the absence of cell death have recently sparked a strong interest in caspase functions in cellular responses beyond apoptosis. Here, we discuss recent data indicating that non-apoptotic functions of caspases involve both proteolysis exerted by their catalytic domains and nonproteolytic functions exerted by their prodomains. Detailed functional analysis of conditional caspase-deficient mice or derived cells confirmed the pleiotropic roles of these proteases in cell differentiation, proliferation and $\mathrm{NF}-\kappa \mathrm{B}$ activation (Table 1). The non-apoptotic functions of caspases suggest that they may become activated independently of - or without - inducing an apoptotic cascade, thus leading to the cleavage of a specific subset of substrates. A list of reported caspase substrates under non-apoptotic conditions is provided in Table 2. These substrates include members of diverse protein families such as cytokines, kinases, transcription factors and polymerases (Table 2). Finally, the regulation of these non-proteolytic functions by the caspase-like decoy molecules c-FLIP (cellular caspase-8 (FLICE)-like inhibitory protein), human caspase-12, COP, INCA and ICEBERG provides additional support for the involvement of caspases in the regulation of cell survival, proliferation, differentiation and inflammation.

\footnotetext{
${ }^{1}$ Unit of Molecular Signalling and Cell Death, Department for Molecular Biomedical Research, Flanders Interuniversity Institute for Biotechnology (VIB), Ghent University, Ghent (Zwijnaarde), Belgium

${ }^{*}$ Corresponding author: P Vandenabeele, Unit of Molecular Signalling and Cell Death, Department for Molecular Biomedical Research, Flanders Interuniversity Institute for Biotechnology (VIB), Ghent University, Technologiepark 927, B-9052 Ghent (Zwijnaarde), Belgium. Tel: +32 933 13 760; Fax: +32 93313 609;

E-mail: peter.vandenabeele@dmbr.ugent.be

${ }^{2}$ Current address: Department of Pathology and Comprehensive Cancer Center, University of Michigan Medical School, 1500 East Medical Center Drive, Ann Arbor, Michigan 48109, U.S.A.

Keywords: caspase; nuclear factor $\kappa \mathrm{B}$; FLIP; proliferation; differentiation; apoptosis; inflammation

Abbreviations: BcR, B-cell receptor; CDK, cyclin-dependent kinase; CMB, CARMA-Bcl10-MALT1; CARD, caspase recruitment domain; caspase, cystein-dependent aspartate-specific protease; DED, death effector domain; DISC, death inducing signalling complex; FLASH, FLICE-associated huge protein; IAP, inhibitor of apoptosis protein; $\mid \kappa \mathrm{B}$, inhibitor of $\kappa \mathrm{B}$; IKK, I $\mathrm{B}_{\mathrm{B}}$ kinase; IL, interleukin; LPS, lipopolysaccharide; LRR, leucine rich repeats; NEMO, NF- $\kappa \mathrm{B}$ essential modulator; NF- $\kappa \mathrm{B}$, nuclear factor $\kappa \mathrm{B}$; PARP, poly(ADP-ribose) polymerase; PIDD, p53-induced death domain protein, RIP, receptor interacting protein; TcR, T-cell receptor; TLR, toll-like receptor; TNF, tumor necrosis factor; TRAF, tumor necrosis factor-receptor associated factor

Received 21.7.06; revised 17.8.06; accepted 18.8.06; Edited by S Kumar; published online 20.10.06
} 
Table 1 Overview of non-apoptotic caspase functions

\begin{tabular}{|c|c|c|}
\hline Caspase & Phenotype & References \\
\hline \multirow[t]{3}{*}{ Caspase-1 } & Cytokine maturation & 97,98 \\
\hline & Induction of pyroptosis & 99,100 \\
\hline & Prodomain-mediated NF- $\kappa$ B activation & 27 \\
\hline \multirow[t]{2}{*}{ Caspase-2 } & Switch between stress-induced NF- $\kappa$ B activation and induction of apoptosis & $6,31,32$ \\
\hline & Prodomain-mediated NF- $\kappa$ B activation & 24 \\
\hline \multirow[t]{4}{*}{ Caspase-3 } & Inhibition of B-cell proliferation & 59 \\
\hline & Inhibition of MHC II expression and dendritic cell maturation & 79 \\
\hline & Proliferation of forebrain cells and keratinocytes & 57,71 \\
\hline & Differentiation of lens epithelial cells, erythroblasts, platelets, myoblasts, osteoblasts and neural stem cells & $56,66,68,75-77$ \\
\hline Caspase-4 & Not determined & \\
\hline Caspase-5 & Maturation of pro-inflammatory cytokines in the inflammasome & 101 \\
\hline Caspase-6 & Not determined & \\
\hline Caspase-7 & Not determined & \\
\hline \multirow[t]{5}{*}{ Caspase-8 } & Proliferation of T, B and NK cells & $14,39,40$ \\
\hline & NF- $\kappa$ B activation following TcR-, TNF-, TLR-4- and Apo2/TRAIL-stimulation & $5,12,16$ \\
\hline & dsRNA-induced NF- $\kappa$ B activation via its prodomain & 25,26 \\
\hline & Differentiation of monocytes into macrophages & 72,73 \\
\hline & Differentiation of placental villous trophoblasts & 74 \\
\hline Caspase-9 & Not determined & \\
\hline Caspase-10 & dsRNA-induced NF- $\kappa$ B activation via its prodomain & 25,26 \\
\hline Caspase-11 & Maturation of pro-inflammatory cytokines & 102 \\
\hline Caspase-12 & Attenuation of inflammation and susceptibility to sepsis & 94,95 \\
\hline Caspase-14 & Terminal differentiation of keratinocytes? & 70,103 \\
\hline
\end{tabular}

Table 2 Caspase substrates in non-apoptotic conditions

\begin{tabular}{|c|c|c|c|}
\hline Cellular process & Substrates & Function & References \\
\hline \multirow[t]{5}{*}{ Cell-cycle regulation } & Wee1 kinase & Inactivated & 104 \\
\hline & P21 Waf1 & Inactivated & 59 \\
\hline & $\mathrm{p} 27^{\mathrm{KIP} 1}$ & Inactivated & $58,105,106$ \\
\hline & NF-AT & Inactivated & 62 \\
\hline & SATB1 (special AT-rich sequence-binding protein 1) & Inactivated & 107 \\
\hline \multirow[t]{2}{*}{ Cytokine maturation } & IL-1 $\beta$ & Activated & 98 \\
\hline & IL-18 & Activated & 97 \\
\hline $\mathrm{NF}-\kappa \mathrm{B}$ activation & PARP-1 & Activated & 18 \\
\hline \multirow[t]{4}{*}{$\mathrm{T}$ and $\mathrm{B}$ cell Activation } & c-FLIP & Activated & 38,48 \\
\hline & Lamin B & Unknown & 104 \\
\hline & PARP-1 & Activated & 104 \\
\hline & Wee1 kinase & Inactivated & 104 \\
\hline \multirow[t]{7}{*}{ Macrophage differentiation } & PAK-2 & Activated & 108 \\
\hline & $\alpha$-Tubulin & Inactivated & 108 \\
\hline & Vinculin & Unknown & 108 \\
\hline & Nucleophosmin & Unknown & 108 \\
\hline & PAl-2 & Inactivated & 108 \\
\hline & hnRNP-H & Unknown & 108 \\
\hline & hnRNP-C1/C2 & Unknown & 108 \\
\hline \multirow[t]{2}{*}{ MHC II-expression and dendritic cell maturation } & $\beta 1$-adaptin & Inactivated & 79 \\
\hline & $\gamma$-Adaptin & Inactivated & 79 \\
\hline \multirow[t]{3}{*}{ Erythrocyte differentiation } & PARP-1 & Inactivated & 68 \\
\hline & Lamin B & Inactivated & 68 \\
\hline & Acinus & Activated & 68 \\
\hline \multirow[t]{2}{*}{ Myoblast differentiation } & MST1 kinase & Activated & 75 \\
\hline & Calpastatin & Inactivated & 109 \\
\hline Lens fiber formation & PARP-1 & Inactivated & 110 \\
\hline Keratinocyte differentiation & $\operatorname{PKC} \delta$ & Activated & 71 \\
\hline
\end{tabular}

\section{Caspase-Mediated NF- $\kappa$ B Activation}

From an evolutionary perspective, the link between caspases and NF- $\kappa$ B activation predates the emergence of mammals. The Drosophila innate immune system discriminates between Gram-positive and Gram-negative pathogens and responds by inducing the expression of specific antimicrobial peptides. ${ }^{8}$
Loss-of-function mutations in the gene encoding the Drosophila caspase-8 ortholog DREDD renders flies highly susceptible to Gram-negative bacteria. ${ }^{9}$ As the phenotype of Dredd knockout flies resembles that of mutants lacking the NF- $\kappa$ B-like factor Relish, it is likely that DREDD functions upstream of Relish to control the production of antibacterial peptides such as drosomycin and metchnikowin. ${ }^{9,10}$ Activation of Relish was 
recently reported to require cleavage at the canonical caspase site $L_{Q H D}{ }_{545}-G_{546} \cdot{ }^{11}$ With the notable exception of DREDD, RNAi-mediated knockdown of the other fly caspases did not affect Relish processing in cells. ${ }^{11}$ However, in vitro reconstitution experiments to confirm direct processing of Relish by DREDD failed so far, ${ }^{11}$ possibly because cleavage occurs in a protein complex in cells. Nevertheless, these results suggest that DREDD may mediate the production of antibacterial peptides through the direct cleavage and activation of this $\mathrm{NF}-\kappa \mathrm{B}$-like transcription factor. In recent years, it has become clear that mammalian caspases fulfil roles in NF- $\kappa$ B activation, attesting to the evolutionarily conserved role of DREDD in Drosophila innate immunity. At least two different molecular mechanisms for caspase-mediated NF- $\kappa \mathrm{B}$ activation in mammals have been suggested.

A first molecular mechanism of caspase-mediated NF- $\kappa$ B activation involves the catalytic activity of large prodomain caspases. Upon T-cell Receptor (TcR) stimulation, caspase-8 and its adaptor protein FADD (Fas-associated death domaincontaining protein) are recruited to the CARMA-Bcl10-MALT1 (CBM) complex. ${ }^{12}$ The paracaspase MALT1 harbours a death domain and a caspase-like domain and is required for TcRinduced NF- $\kappa$ B activation. ${ }^{13}$ As demonstrated by means of reconstitution experiments in patient-derived caspase-8 deficient $\mathrm{T}$ cells, this $\mathrm{TcR}$-induced $\mathrm{NF}-\kappa \mathrm{B}$ activation apparently depends on enzymatically active, although unprocessed, caspase-8 for the recruitment of the IKK complex. ${ }^{12}$ Studies with biotinylated-zVAD-fmk revealed that only a minor fraction of the total caspase-8 pool in Jurkat T cells became enzymatically active after TcR stimulation. ${ }^{12}$ In contrast, Salmena et al. ${ }^{14}$ could not observe differences in TcRstimulated NF- $\kappa$ B activation in caspase $-8^{-1-}$ mouse $T$ cells. This discrepancy might be due to the fact that $\mathrm{NF}-\kappa \mathrm{B}$ activation in the caspase-8-deficient mouse $\mathrm{T}$ cells was determined quite late after TcR stimulation (6h). The importance of kinetics in $\mathrm{NF}-\kappa \mathrm{B}$ signalling pathways is underscored by observations in TRAF2-deficient cells. Indeed, the absence of TRAF2 only delays the kinetics of $\mathrm{NF}-\kappa \mathrm{B}$ activation in response to TNF, while at a later time point (90 min), the extent of activated NF- $\kappa$ B in TRAF2 deficient cells is equivalent to that in control cells. ${ }^{15}$ Remarkably and in agreement with the observations in fibroblasts and epithelial cells, ${ }^{16}$ the enzymatic activity of caspase- 8 is dispensable for TNF-induced NF- $\kappa$ B activation in T cells. ${ }^{12}$ These observations suggest that in $T$ cells, the enzymatic activity of caspase8 may only be required for NF- $\kappa$ B activation in response to a specific subset of NF- $\kappa \mathrm{B}$-activating agents.

In certain cell types (HT1080 human fibrosarcoma, Jurkat $T$ cells, SK-MES-1 human lung squamous carcinoma and A549 human lung carcinoma), RNAi-mediated knockdown of caspase-8 was shown to impede or delay Apo2L/TRAILinduced NF- $\kappa$ B activation. ${ }^{5}$ The release of FADD from the primary TRAIL-R-associated DISC complex would trigger the formation of a secondary signalling complex, which lacks TRAIL-R but contains FADD, caspase-8, RIP1, TRAF2 and/or NEMO. ${ }^{5}$ The latter cytosolic protein complex would mediate the activation of $\mathrm{JNK}, \mathrm{p} 38$ and NF- $\kappa \mathrm{B} .{ }^{5}$ As the pan-caspase inhibitor z-VAD-fmk significantly delayed Apo2/TRAIL-induced $I_{\kappa} \mathrm{B}$ phosphorylation and secondary complex formation, the authors proposed that the enzymatic activity of caspase-8 is required for the dissociation of FADD from the TRAIL-R and for subsequent secondary complex formation. ${ }^{5}$ However, it cannot be excluded that the identified signalling complex is formed in response to general apoptotic stress, independently from the TRAIL-R-bound DISC complex, as NF $-\kappa$ B activation upon TRAIL-receptor stimulation is observed rather late (hours) as compared to TNF-induced NF$\kappa \mathrm{B}$ activation (minutes). Undoubtedly, the precise role of caspase- 8 in these NF- $\kappa \mathrm{B}$ signalling cascades and the identity of its substrates under NF- $\kappa \mathrm{B}$-activating conditions warrant further investigation.

Besides the role of caspase- 8 in Apo2L/TRAIL- and TcRmediated activation of $\mathrm{NF}-\kappa \mathrm{B},{ }^{5,12}$ also short prodomain caspases may be involved in NF- $\kappa \mathrm{B}$ activation. Cleavage of poly-(ADP-ribose) polymerase-1 (PARP-1) has been used for years as a hallmark of caspase-3/-7 activation and apoptosis. PARP-1 cleavage during apoptosis impairs the DNA repair capacity of the cell. ${ }^{17}$ Recently, however, caspase-generated PARP-1 fragments were implicated in an inflammatory response. Macrophages from knock-in mice expressing caspase-resistant PARP-1 show an impaired LPS-induced NF- $\kappa$ B-mediated gene activation despite normal binding of NF $-\kappa$ B to DNA. ${ }^{18}$ Thus, caspase -3 and -7 would apparently propagate the transactivation, rather than the nuclear translocation of NF- $\kappa$ B through a PARP-1-mediated mechanism. ${ }^{18}$ This hypothesis is underscored by the observation that caspase-generated PARP-1 fragments can interact with both the $\mathrm{p} 50$ and $\mathrm{p} 65$ subunit of $\mathrm{NF}-\kappa \mathrm{B}$ and with the transcriptional co-activator p300. ${ }^{19,20}$ The observed resistance to endotoxic shock and to intestinal and renal ischemia-reperfusion of caspase-resistant PARP-1 knock-in mice further supports the in vivo contribution of executioner caspases to inflammatory responses. $^{18}$ These results demonstrate that caspasemediated PARP-1 cleavage under non-apoptotic conditions can contribute to the level of NF- $\kappa \mathrm{B}$ transcriptional activity. However, it is still unresolved whether this contribution to NF$\kappa \mathrm{B}$ transcriptional activity depends on a structural role and/or the poly(ADP-ribose) polymerase activity of PARP-1. On the one hand, it is shown that co-activation of NF- $\kappa$ B by $p 300$ in TNF- or LPS-stimulated primary fibroblasts or macrophages does not depend on the enzymatic activity of PARP-1, whereas on the other hand, studies using PARP-1 inhibitors do indicate a role for PARP-1 enzymatic activity in the enhancement of NF- $\kappa \mathrm{B}$ transcriptional activity. ${ }^{21,22}$ Further analysis is required to clarify this intriguing issue.

A second mechanism to propagate the activation of NF- $\kappa \mathrm{B}$ makes use of the CARD and DED motifs present in the prodomains of specific caspases. ${ }^{23-25}$ This is underscored by the observation that transient expression of caspase-1, -2, -8 and -10 are able to activate NF- $\kappa \mathrm{B}$ whereas murine caspase9, -11 and -12 are not. ${ }^{24-27}$ Caspase-1 CARD specifically recruits the CARD-containing kinase RIP2, which is involved in Toll-like receptor (TLR)- and TcR-mediated NF- $\kappa$ B activation. ${ }^{28}$ The involvement of RIP2 in caspase-1 CARD-induced $\mathrm{NF}-\kappa \mathrm{B}$ activation is demonstrated by the inhibition of the latter by expression of a RIP2 dominant-negative mutant. ${ }^{27}$ Recently, this caspase-1/RIP2 interaction was shown to be modulated by the adaptor molecule ASC, which also interacts with caspase-1 via its CARD. ${ }^{29}$ ASC interferes with the caspase-1/RIP2 interaction and inhibits the subsequent 
$\mathrm{NF}-\kappa \mathrm{B}$ activation in a dose-dependent fashion, while stimulating caspase-1-dependent pro-IL-1 $\beta$ maturation. ${ }^{29}$ Consistent with a role for ASC as an inhibitor for caspase-1/RIP2-induced $N F-\kappa B$ activation, siRNA-induced knockdown of ASC in THP1 cells leads to higher NF- $\kappa$ B activation levels, while caspase1 activation and release of mature IL-1 $\beta$ are diminished. ${ }^{29}$ Altogether, these results suggest that caspase-1 may contribute to pro-IL-1 $\beta$ processing through its enzymatic activity, while its interaction with RIP2 induces NF- $\kappa \mathrm{B}$ activation. Furthermore, ASC may function as a switch that directs caspase- 1 away from RIP2-mediated NF- $\kappa$ B activation towards the maturation of pro-IL-1 $\beta$ in the inflammasome complexes.

The CARD motif in the prodomain of caspase-2 can mediate the recruitment of TNF receptor-associated factor 2 (TRAF2) and the death domain-containing receptor-interacting protein 1 (RIP1) in an endogenous caspase-2 complex, capable of inducing the activation of NF- $\kappa \mathrm{B} .{ }^{24}$ Recently, the caspase- 2 containing PIDDosome ${ }^{6}$ has been extended with the proteins NEMO and RIP1, explaining the activation of NF$\kappa \mathrm{B}$ following genotoxic stress. ${ }^{30,31}$ It is claimed that the active $\mathrm{NF}-\kappa \mathrm{B}$ pathway blocks or delays the caspase-2-mediated cell death pathway as caspase-2 activation is highly accelerated in $\mathrm{RIP}^{-1-}$ cells. The PIDDosome may thus act as an integrator or molecular switch between inflammatory/antiapoptotic and apoptotic signalling pathways following DNA damage. ${ }^{32}$ However, a crucial physiological role of caspase-2 in this pathway, remains to be established and may not be likely or highly redundant, as caspase $-2^{-/-}$mice do not display an overt phenotype. ${ }^{33}$

Following TNF-R1 triggering, caspase-8 reportedly forms a complex with TRAF2 and FLASH (FLICE-associated huge protein) to initiate the NF- $\kappa \mathrm{B}$ activation pathway. ${ }^{16}$ In agreement with these findings, TNF-induced NF- $\kappa \mathrm{B}$ activation in fibroblast and epithelial cell lines depends on caspase-8, as underscored by the abrogation of $\mathrm{NF}-\kappa \mathrm{B}$ activation by antisense-mediated depletion of caspase-8. ${ }^{16}$ However, as discussed above, the enzymatic activity of caspase- 8 seems to be dispensable for TNF-induced NF- $\kappa$ B activation in these cells. In this respect, caspase- 8 is known to associate with TRAF2 and FLASH through the DED motifs present in its $N$ terminal prodomain. ${ }^{16}$ Furthermore, the caspase- 8 prodomain is reportedly capable of inducing NF- $\kappa \mathrm{B}$ activation independent of caspase-8 enzymatic activity. ${ }^{23-25}$ Altogether, these results suggest a structural caspase-8 requirement for TNF-induced NF- $\kappa$ B activation through its DED-dependent interaction with TRAF2 and FLASH, independent of caspase8 catalytic activity.

It is conceivable that prodomain fragments generated through limited caspase autoactivation are implicated in $\mathrm{NF}-\kappa \mathrm{B}$ signalling. Indeed, such a mechanism would provide an elegant framework to explain the available data on caspase catalytic activity-dependent and -independent mechanisms and may suggest that the release of CARD- and DED-containing prodomain fragments (from caspases and caspase-like molecules) is the principal target of caspase activation during NF- $\kappa \mathrm{B}$ signalling (Figure 1 ). In this respect, dsRNA-induced NF- $\kappa$ B activation was recently suggested to require the released prodomains of caspase- 8 and -10 downstream of the cytoplasmic RNA helicases retinoic acid- inducible gene I (RIG-I) and melanoma differentiationassociated gene 5 (MDA5) as these caspases become processed upon dsRNA stimulation. ${ }^{26}$ This model is further supported by the observation that overexpression of small amounts of the corresponding prodomain-encoding constructs strongly activated NF- $\kappa \mathrm{B}$, while full-length caspasesencoding constructs failed to do so. ${ }^{26}$ Finally, the induction of inflammatory cytokines in response to dsRNA was significantly reduced in caspase-8- and -10-deficient cells. ${ }^{26}$ In addition to the possible role of autocatalytically released caspase- 8 and -10 prodomain fragments in antiviral signalling, other lines of evidence implicate caspase-generated DED-containing cFLIP fragments in NF- $\kappa$ B signalling. Indeed, caspase-8-mediated cleavage of $C-F L I P L$ to $P 43^{\text {FLIP }}$ has been shown to induce NF- $\kappa$ B activation via a $443^{\mathrm{FLIP}} /$ caspase-8/ TRAF2 complex (Figure 2). ${ }^{34-37}$ Alternatively, Golks et al. ${ }^{38}$ discovered that a shorter caspase-8-generated N-terminal fragment of $c-F L I P L$, so called p22-FLIP, corresponding to the prodomain region of C-FLIP by cleavage at Asp198, is a key mediator of activation-induced NF- $\mathrm{KB}$ activation in lymphocytes and dendritic cells by binding directly the IKK complex (Figure 2). The physiological and molecular contexts that control caspase-8-mediated cleavage of c-FLIP to either p43 ${ }^{\text {FLIP }}$ or p22-FLIP warrant further study.

\section{Caspases in Cell-Cycle Control and Proliferation}

Several studies demonstrate an essential role for caspase-8 in the proliferation of immune cells. ${ }^{12,14,39,40}$ Patients bearing inactivating mutations in caspase-8 endure impaired proliferation of $\mathrm{T}, \mathrm{B}$ and natural killer (NK) cells. $^{39}$ Similarly, peripheral murine $\mathrm{T}$ cells in which caspase-8 is conditionally deleted are unable to proliferate following TcR activation. ${ }^{14}$ Interestingly, this mouse model recapitulates certain aspects of the disorder described in humans with caspase- 8 mutations. ${ }^{14,39}$ Indeed, caspase- 8 deficient T cells of both murine and human origin display decreased IL-2 production following CD3/CD28 stimulation. ${ }^{14,39}$ The function of caspase-8 upstream of IL-2 production and human T-cell proliferation is confirmed by the requirement of caspase- 8 catalytic activity in TcR-induced activation of $\mathrm{NF}-\kappa \mathrm{B},{ }^{12}$ as discussed above. Based on these findings, T-cell-specific deletion of caspase-8 in mice was concluded to recapitulate the immunodeficiency identified in humans with caspase- 8 mutations. ${ }^{14,39}$ These patients succumb frequently to microbial infections as a result of their inability to activate T, B, and NK cells. ${ }^{39}$ Somewhat paradoxically, however, is that humans with a germline point mutation in the caspase- 8 gene reportedly manifest lymphoadenopathy and splenomegaly, conditions associated with autoimmunity instead of immunodeficiency. ${ }^{39} \mathrm{~A}$ recent report on the long-term effects of T-cell-specific deletion of the caspase- 8 gene in mice describes a similar age-dependent lethal lymphoproliferative and lymphoinfiltrative phenotype characterized by lymphoadenopathy, splenomegaly, and accumulation of T-cell infiltrates in the lungs, liver and kidneys. ${ }^{41}$ Moreover, T cells isolated from old animals were found to be constitutively active, possibly explaining the observed pathological phenotypes. ${ }^{41}$ Thus, loss of caspase- 8 leads to a complex immune condition manifesting features of immunodeficiency and autoimmunity. Noteworthy is that the 


\section{Caspase-8}

a

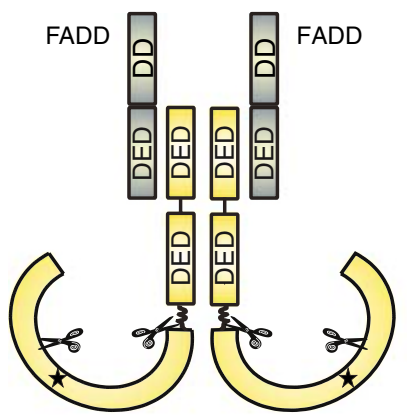

Autoprocessing caspase-8 Release from complex b

Procaspase-8/

c-FLIP dimer

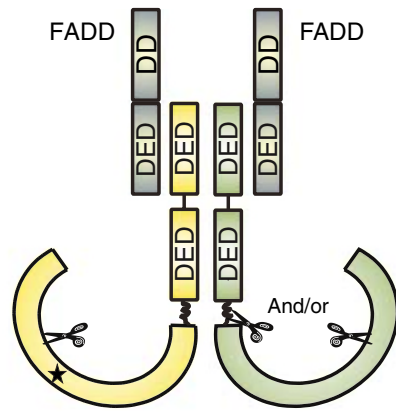

Limited autoprocessing caspase-8 Remains in complex Cleaves only local substrates e.g. C-FLIP
C<smiles>CC=[Te]C=[Te]</smiles>
dimer

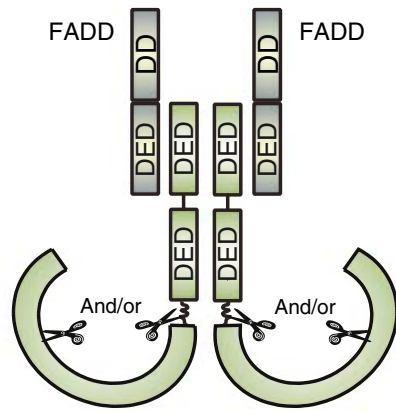

Residual caspase-8 activity assures cleavage of $\mathrm{c}-\mathrm{FLIP}_{\mathrm{L}}$

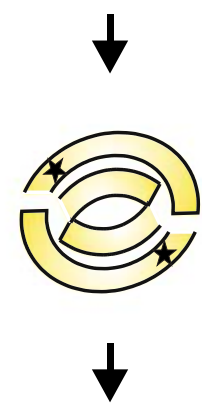

$\downarrow$

\section{APOPTOSIS}

NF- $\mathrm{KB}$ activation

Figure $1 \quad c-F L I P_{L}$ levels modulate caspase-8 activation and downstream signalling. (a) In the absence of c-FLIP , procaspase-8 dimerization leads to full processing and activation of procaspase-8. Active caspase-8 released from the DISC initiate apoptotic signalling pathways through the cleavage of cytosolic substrates. (b) At low concentrations of c-FLIP $P_{L}$, procaspase-8 preferably forms heterodimers with c-FLIP $\mathrm{P}_{\mathrm{L}}$. In these conditions, limited procaspase-8 autoprocessing occurs and active heterodimers remain associated with the DISC complex. Autoprocessing occurs either between the prodomain and the caspase domain or between the p20 and p10 subunits of the caspase domain. Depending on the specific subset of substrates that is cleaved, either apoptosis or NF- $\kappa B$ activation can ensue. (c) High concentrations of $c-F L I P L$ prevent procaspase-8 recruitment and autoprocessing in the DISC. Basal caspase- 8 activity ensures C-FLIPL cleavage and subsequent NF- $\kappa B$ activation

immune defects observed in patients with defective caspase8 are clearly different from those observed in patients with caspase-10 deficiency, suggesting that these two gene products may also have non-redundant functions in T-cell proliferation. ${ }^{39,42}$ Indeed, humans harbouring caspase-10 point mutations display defective FasL- and TRAIL-induced apoptosis, resulting in the accumulation of lymphoid cells, which is characteristic for type II autoimmune lymphoproliferative syndrome (ALPS type II). ${ }^{42}$ Interestingly, the homozygous V410I mutation that correlates with the ALPS type II phenotype in one kindred of this study ${ }^{42}$ was subsequently found to be present as a heterozygous polymorphism in approximately $6.8 \%$ of the Danish population. ${ }^{43}$ Screening of a larger number of healthy individuals is required to resolve whether homozygosity in this polymorphism contributes to the ALPS type II phenotype. Nevertheless, the fact that caspase10 has no ortholog in mice, but may compensate for specific caspase-8 functions in human cells, may explain the moderate phenotype of caspase- 8 mutations in humans as compared to the embryonic mortality of mice with a targeted deletion of caspase- 8 . $^{44}$

There are some contrasting findings on the role of caspase8 in NF- $\kappa$ B activation and proliferation in B cells, depending on the species. In mice, LPS or dsRNA-induced proliferation of caspase-8-deficient $B$ cells is impaired, although TLR-4induced activation of NF- $\kappa \mathrm{B}$ is not impeded in these cells. ${ }^{40}$ In human $B$ cells harbouring homozygous caspase- 8 mutations, both NF- $\kappa \mathrm{B}$ activation and proliferation are abrogated. ${ }^{12}$ Whether human and mouse caspase-8-deficient $B$ cells respond differently because of the different nature of caspase-8 deficiency, the initiation of different signalling pathways or of different experimental set-ups to analyse the activation of $\mathrm{NF}-\kappa \mathrm{B}$ is not clear to date. If this discrepancy resists scrutiny, it would suggest a role for caspase-8 in 


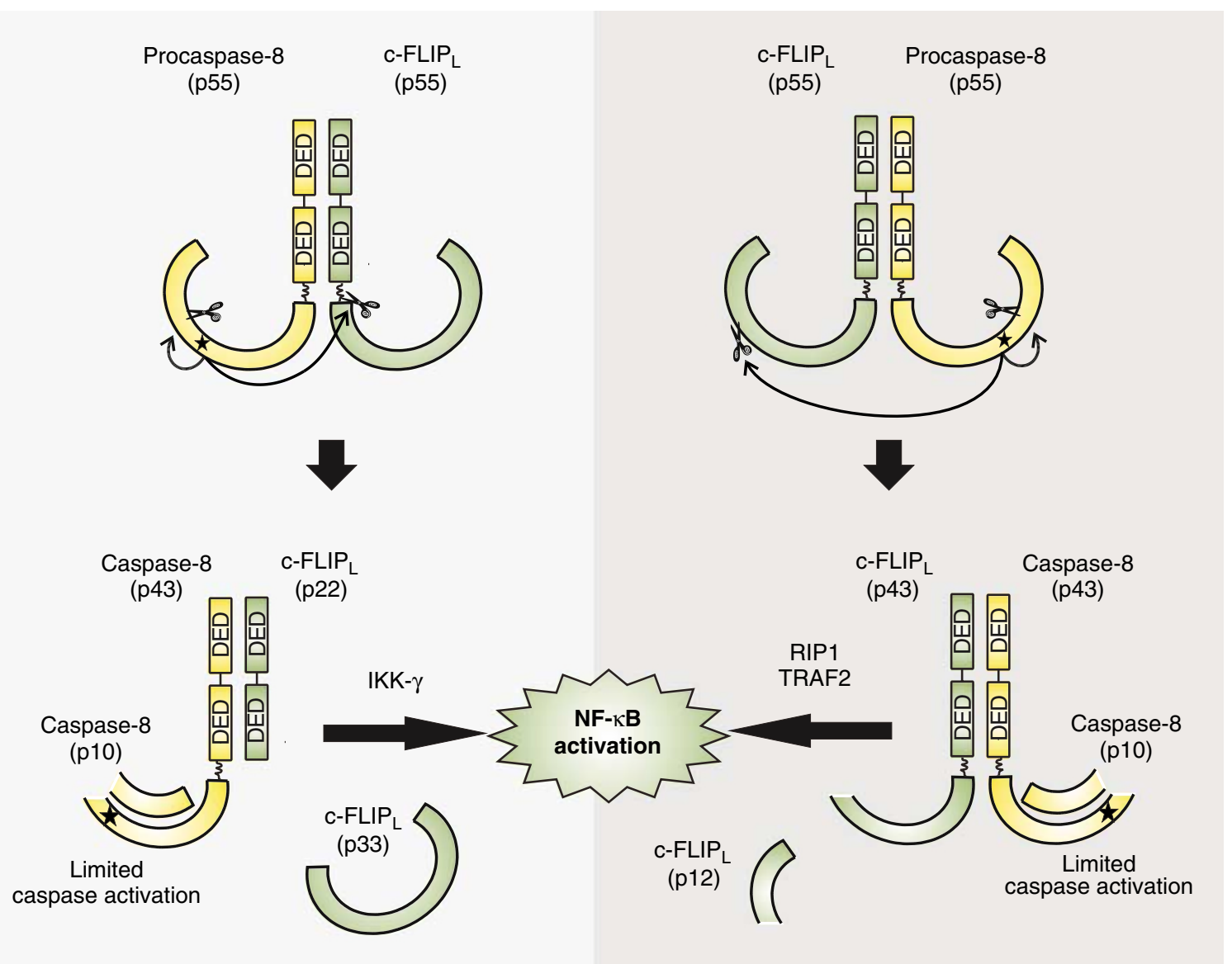

Figure 2 Molecular mechanisms of $c-F L I P_{L}-$ mediated NF- $\kappa B$ activation. Two models of $c-F L I P_{L}$-induced NF- $\kappa B$ activation have been proposed: (left) Caspase-8mediated cleavage of c-FLIP $\mathrm{L}_{\text {at }}$ Asp 198 in lymphocytes and dendritic cells releases a $22 \mathrm{kDa}$ fragment (p22-FLIP), essentially comprising the two $\mathrm{N}$ terminal DED motifs. P22FLIP interacts directly with NEMO/IKK- $\gamma$ in the IKK complex, leading to NF- $\kappa$ B activation. (right) Caspase-8 cleaves c-FLIP $P_{L}$ at Asp376 to generate an N terminal p43 ${ }^{\text {FLIP }}$ fragment, which subsequently recruits TRAF2 and RIP1 to induce NF- $\kappa$ B activation. $\star$, catalytic cysteine in the conserved QACQG motif of caspase-8

mouse B-cell proliferation independent of $\mathrm{NF}-\kappa \mathrm{B}$ signalling and may reveal additional caspase- 8 functions that may contribute to the phenotype of caspase-8-deficient human $B$ cells.

Caspase-8 thus can initiate apoptosis, but is also implicated in the activation of $\mathrm{NF}-\kappa \mathrm{B}$ and regulation of lymphocyte proliferation. Whether the outcome of caspase- 8 activation is apoptotic or non-apoptotic is most probably determined by the extent of its activation (Figure 1). In proliferating cells, caspase-8 remains unprocessed and becomes only weakly activated. $^{12}$ In contrast, caspase- 8 processing and strong activation is seen during FasL-induced apoptosis (Figure 1a). ${ }^{4}$ An important player in the regulation of caspase- 8 activation at the level of the DISC is C-FLIP,$a$ caspase-8-like molecule that lacks caspase activity. ${ }^{45,46} \mathrm{At}$ low concentrations of $\mathrm{C}-\mathrm{FLIP}$, procaspase- 8 activation is enhanced due to the ability of $C-F L I P L$ to form a heterodimeric chimeric enzyme with caspase- $8^{34,46,47}$ even more efficiently than caspase- 8 homodimers. ${ }^{47}$ In these conditions, limited caspase-8 autoprocessing occurs, but the presence of cFLIP $_{\mathrm{L}}$ ensures that caspase activity remains in the complex (Figure 1b). Therefore, only DISC proximal substrates such as caspase-8 itself, C-FLIPL and RIP1 are cleaved, whereas cytosolic substrates such as Bid are not. ${ }^{46}$ At this point, either apoptosis or apoptosis-independent functions of caspase-8 such as $\mathrm{NF}-\kappa \mathrm{B}$ activation and cell proliferation can ensue (Figure $1 \mathrm{~b}){ }^{37,48}$ At high concentrations of $\mathrm{c}-\mathrm{FLIP}_{\mathrm{L}}$, recruitment of caspase- 8 to the DISC is strongly prevented and caspase- 8 processing is impeded, thus blocking the induction of cell death while promoting FLIP $_{\mathrm{L}}$-mediated NF- $\kappa \mathrm{B}$ activation (Figure 1c). ${ }^{34,49}$

Viral FLIP molecules resemble c-FLIP in that they also bear two DEDs. ${ }^{50}$ Unlike the v-FLIP molecules E8 (from the Equine Herpes Virus 2) and MC159L (from the Molluscum Contagiousum virus), the Human Herpes Virus 8 (HHV-8)encoded v-FLIP $\mathrm{K} 13$ can also activate NF- $\kappa \mathrm{B}$ next to its capacity to block cell death. ${ }^{51}$ This different behaviour of $\mathrm{v}$-FLIP molecules towards the activation of NF- $\kappa \mathrm{B}$ is comparable to the observation that some prodomains of CARDcontaining caspases can induce the activation of NF- $\kappa \mathrm{B}$ whereas others cannot. ${ }^{24,27}$ Transgenic overexpression of HHV-8 v-FLIP in the lymphoid compartment leads to constitutive NF- $\kappa \mathrm{B}$ activation and increased incidence of lymphomas, but does not affect Fas-induced apoptosis or the development and maturation of lymphocytes. ${ }^{52}$ Similar to HHV-8 v-FLIP-overexpressing splenocytes and thymocytes, 
c-FLIP $P_{L}$ expression in transgenic $(\mathrm{tg})$ mice causes the $T$ cells to hyperproliferate upon activation. ${ }^{48,52,53}$ The proliferative response of $C-F_{L I P} \operatorname{tg} \mathrm{CD}^{+}{ }^{+} \mathrm{T}$ cells is dependent on caspase activity as proliferation is largely inhibited by the pan-caspase inhibitors zVAD-fmk and QVD-Oph. Additionally, an increase in NF- $\kappa \mathrm{B}$ activity was observed 2 days after activation of the C-FLIP tg CD8 $^{+}$T cells. ${ }^{48}$ Active caspase- 8 cleaves $\mathrm{C}-\mathrm{FLIP}_{\mathrm{L}}$ to generate a p43 ${ }^{\mathrm{FLIP}}$ fragment. ${ }^{34-36} \mathrm{p} 43^{\mathrm{FLIP}}$ was shown to interact with TRAF2 and induce NF- $\kappa \mathrm{B}$ activation via a $\mathrm{p} 43^{\mathrm{FLIP}} /$ caspase-8/TRAF2 complex (Figure 2). ${ }^{37}$ The activation of NF- $\kappa$ B by this ternary complex could be mediated by RIP1, since the latter is also able to bind to $p 43^{\mathrm{FLIP} 48}$. Moreover, a dominant-negative form of RIP1 that contains only the death domain was able to prevent $p 43^{\mathrm{FLIP}}$-induced NF- $\kappa$ B activity. ${ }^{48}$ These results demonstrate that the NF- $\kappa$ Bactivating and concomitant proliferation-enhancing function of c-FLIP involves RIP1.

Mice conditionally lacking c-FLIP in T lymphocytes display severe defects in the development and proliferation of mature T cells, ${ }^{52,54}$ although TcR-induced activation of NF- $\kappa \mathrm{B}$ is not affected. ${ }^{54}$ On the contrary, in caspase- 8 deficient $T$ cells both TcR-induced NF- $\kappa \mathrm{B}$ activation and T-cell proliferation are abolished. ${ }^{12,14,39}$ These results suggest that besides common mechanisms of NF- $\kappa$ B activation involving RIP1, caspase-8 possesses additional ways for TcR-induced NF- $\kappa$ B activation, which most probably involve its catalytic activity. If we compare the phenotypes related to TcR-induced proliferation and $\mathrm{NF}-\kappa \mathrm{B}$ activation in different human and mouse models, the following conclusions can be formulated. TcR-induced proliferation is reduced in the absence of c-FLIP, caspase-8 or FADD, indicative of their functions in a common pathway initiated by stimulation of the TcR. The precise roles of these molecules in the NF- $\kappa \mathrm{B}$ activation pathway(s) remain to be determined. Analysis of the NF- $\kappa \mathrm{B}$ signalling cascades in transgenic mice overexpressing the caspase- 8 inhibitor $\mathrm{CrmA}$ (cytokine response modifier $A)^{55}$ could help to elucidate the contribution of the protease activity of caspase-8. As mentioned above, TcR-induced NF- $\kappa$ B activation is required ${ }^{56}$ but not sufficient for T-cell proliferation and activation to occur. ${ }^{54}$ The crucial factor or cellular condition determining the switch between FADD/caspase-8-mediated proliferation and FADD/caspase-8-mediated apoptosis is still unresolved. It is conceivable that accessibility and specific proteolysis of particular caspase-8 substrates may influence this switch.

Short prodomain caspases, in particular caspase-3, were recently shown to exert several non-apoptotic functions as well. The subcellular localization and the proteolysis of substrates associated with cell cycle control suggest a function of caspase-3 in the modulation of cell growth. For example, nuclei of dividing cells in the proliferative regions of rat forebrain display the presence of active caspase- $3 .{ }^{57}$ In proliferating lymphoid cells, caspase-mediated cleavage of the cyclin-dependent kinase (CDK) inhibitor p27 $27^{\mathrm{KIP} 1}$ contributes to the induction of cell cycle progression. ${ }^{58}$ In contrast, hyperproliferation of B cells is observed in caspase-3 knockout mice, indicating that caspase- 3 may act as a negative regulator of $B$-cell cycling. ${ }^{59}$ Although the CDK inhibitor p21 is a known inhibitor of cell cycle progression, p21 can also promote cell proliferation when associated with PCNA, a processivity factor which promotes entry into mitosis. ${ }^{60}$ In line with these observations, caspase-3-mediated cleavage of p21 at the $C$ terminal PCNA-binding site specifically abolishes interaction of p21 with PCNA, thus explaining the antiproliferative effect of this cleavage event in B cells. ${ }^{59,61}$ Analogous studies in conditional knockout mice may reveal additional roles for caspases in cell cycle regulation. Indeed, the transcription factor nuclear factor for activated T cells (NFAT) was recently reported to be a caspase- 3 substrate in cycling $T$ cells. ${ }^{62}$ Interestingly, NF-AT protein levels and NF-AT transcriptional activity are significantly reduced in non-apoptotic $T$ cells from $C-$ FLIP $_{L}$ tg mice, which manifest elevated caspase activity. ${ }^{62}$

The pleiotropic functions of mammalian caspases have recently also been reported to occur in Drosophila. For example, Hay et al. ${ }^{63}$ demonstrated in an elegant setting that caspases can mediate from the same cell a paradoxical combination of pro-apoptotic and proliferative signals. When a large number of cells in the Drosophila wing disc are lost through injury, these cells are known to be compensated for by the proliferation of adjacent cells. ${ }^{64}$ Apparently, the enzymatic activity of the Drosophila caspase Dronc in the dying cells drives the proliferation of neighbouring cells to restore the wings. ${ }^{63}$ The molecular signalling cascade that connects this pro-apoptotic caspase to the compensatory proliferation of adjacent cells remains to be uncovered, but one could envision cleavage of a substrate that leads to the secretion of the growth-stimulating factors wingless and decapentaplegic, hence inducing proliferation of nearby nonaffected cells in a Dronc-dependent manner. This mechanism is reminiscent of apoptotic cells inducing tissue repair mechanisms in mammalian tissues. Indeed, phagocytosis of apoptotic Jurkat $T$ cells and peritoneal macrophages leads to the secretion of growth and survival factors such as vascular endothelial growth factor (VEGF), which subsequently promote growth of endothelial and epithelial cells in a paracrine fashion. ${ }^{65}$ These processes may in fact reflect one of the primary functions of caspases, that is the restoration of homeostasis after tissue damage by forming the link between cell death through apoptosis and the induction of tissue repair.

\section{Caspases in Cell Differentiation}

Several reports have demonstrated that caspases are involved in the terminal differentiation of a variety of cell types involving enucleation processes such as lens cell differentiation, erythrocyte and platelet formation and the terminal differentiation of keratinocytes. Caspase-3 activity is apparently required for the maintenance of lens transparency, since caspase $-3^{-1-}$ mice exhibit marked cataracts at the anterior lens pole. ${ }^{66}$ These authors also presented genetic evidence that neither loss of any single executioner caspase $(-3,-6,-7)$ nor simultaneous loss of caspase -3 and -6 prevents organelle loss during lens development. These results appear to contradict studies using synthetic inhibitors, ${ }^{67}$ which claimed a role for executioner caspases in terminal differentiation of lens epithelial cells into anucleate lens fibers. The terminal differentiation of human and murine erythroblasts also requires caspases. Caspase inhibitors interfere with the maturation of erythroid progenitors at an early stage of differentiation. $^{68}$ Caspases- $-2,-3$ and -9 are transiently 
activated during erythroblast differentiation and are involved in the cleavage of the nuclear proteins Lamin B, PARP and Acinus. ${ }^{68}$ These caspase substrates are implicated in chromatin condensation and enucleation, features characteristic of erythrocyte differentiation. Platelets are a third type of enucleate cells, and their formation from mature megakaryocytes coincides with caspase- 3 and -9 activation. ${ }^{56}$ Furthermore, synthetic caspase inhibitors block platelet formation in vitro, underscoring the role of caspases in their differentiation. ${ }^{56}$ In addition, it was suggested that caspases are involved in platelet activation events, such as phosphatidylserine exposure and release of microparticles. ${ }^{69}$ In the epidermis, the terminal differentiation of keratinocytes into enucleated corneocytes coincides with the expression and processing of caspase-14. ${ }^{70}$ No specific inhibitors of this caspase or mice deficient in it have been reported yet. Therefore, the involvement of this caspase in the terminal differentiation of the skin remains to be established. Interestingly, it was recently shown that caspase-3 is activated in the embryonic epidermis, but not in newborn epidermis. ${ }^{71}$ Lack of caspase-3 resulted in increased proliferation and reduced differentiation of embryonic keratinocytes.

The differentiation processes discussed above all result in enucleated cells, namely lens cells, erythrocytes, megakaryocytes and keratinocytes. As enucleated cells are a biological dead end, these terminal differentiation processes could be regarded as specialized forms of programmed cell death in which the body corpses are not removed by phagocytosis, but remain and are functional. However, caspases do also promote differentiation of cells without inducing any form of programmed cell death. One example is the differentiation of human blood monocytes into macrophages, a process that is blocked by synthetic caspase inhibitors. ${ }^{72}$ In addition, genetic deletion of caspase- 8 in cells of the myelomonocytic lineage prevented them from differentiating into macrophages upon treatment with M-CSF. ${ }^{73}$ Interestingly, the activation of caspases seems to be specifically associated with differentiation into macrophages, and not with monocytes undergoing dendritic cell differentiation. ${ }^{72}$ Using antisense oligonucleotides and caspase inhibitors, it was shown that activation of caspase- 8 is essential during differentiation of human placental villous trophoblasts. ${ }^{74}$ Another report established a role for caspase-3 in skeletal muscle differentiation: primary myoblasts from caspase-3 knockout mice displayed a severe lack of myotube and myofiber formation and a reduced expression of musclespecific genes. ${ }^{75}$ Furthermore, the authors identified the serine/threonine Mammalian Sterile Twenty-like kinase (MST1) as a crucial effector of caspase-3, since a proteolytic fragment of MST1 rescued the differentiation defect of caspase- 3 deficient myoblasts. ${ }^{75}$ In line with these results, caspase-3 null mice that survive to early perinatal life are significantly smaller than heterozygous littermates and reportedly have a lower total skeletal muscle mass. ${ }^{75}$ Moreover, ossification is delayed and bone mineral density is decreased in caspase-3 deficient mice due to attenuation of osteogenic differentiation. ${ }^{76}$ More recently, this protease was suggested to contribute to neural stem cell differentiation based on experiments with ex vivo cultured caspase- 3 null neurospheres. ${ }^{77}$ Similarly, the development of Drosophila proneural clusters in the wing imaginal disc was recently shown to require tight control of caspase activation. This is achieved by the IKK-related kinase DmIKK $\varepsilon$, which phosphorylates and targets the caspase inhibitor DIAP for proteasomal degradation. ${ }^{78}$ In contrast to these roles of caspases as positive regulators of cell differentiation, constitutive caspase3 activity in immature dendritic cells was found to block dendritic cell maturation and cell-surface expression of peptide-loaded major histocompatibility complex (MHC) class II molecules. ${ }^{79}$ Caspase-3-mediated cleavage of the $\beta 1$ - and $\gamma$-subunits of the adaptor protein 1 (AP1) complex was discovered to be the underlying molecular event. ${ }^{79}$ Treatment with pharmacological caspase inhibitors or LPS inhibited AP-1 cleavage and initiated dendritic cell maturation. ${ }^{79}$ Finally, the Drosophila caspases DREDD, DRONC and drICE were all described to be essential for spermatid individualization and the proper differentiation of sperm cells. ${ }^{80,81}$ The impaired sperm differentiation resulting from caspase inhibition in Drosophila strikingly resembles one of the most commonly seen abnormalities of human spermatozoa, known as cytoplasmic droplet sperm. ${ }^{82}$ In this respect, mutations in several apoptotic mouse genes - although not identified in mammalian caspase genes - are known to produce defects in spermatogenesis and lead to male sterility. ${ }^{83}$ Interestingly, spermatogenesis and fertility of male Apaf-1-deficient mice that reach adulthood depends on the genetic background of the animals: while Apaf-1 null mice in a mixed 129/ICR background are infertile, some male mutants kept in a C57BL/ 6 background succeed in impregnating females. ${ }^{84}$ These data indicate that it would be wise to assess the effect of potential therapeutic caspase inhibitors on human fertility before entering the clinic.

\section{Caspases in Cell Motility}

Regulation of cell migration is another emerging nonapoptotic function of caspases. DIAP-mediated inhibition of the caspase- 9 homologue DRONC has been found to be essential for border-cell migration in the Drosophila ovary. ${ }^{85}$ Border-cells form clusters of supporting cells that assist in the proper development of oocytes in the Drosophila ovary. The cleavage of several adhesion- and cell motility-related proteins during mammalian apoptosis may also point to a role in the regulation of cell migration. ${ }^{86}$ Recent findings are in support of this suggestion as cell migration is severely hampered in caspase-8-deficient cells and CrmA-overexpressing cells. The authors propose a model in which caspase-8 promotes Rac activation and subsequent cytoskeletal remodelling downstream of calpains. ${ }^{87}$ Furthermore, the earlyembryonic death of caspase- $8^{-1-}$ mice is mainly attributed to their failure to assemble a functional circulatory system, possibly reflecting an underlying defect in endothelial cell migration. ${ }^{44}$ These observations warrant further investigations of the molecular mechanisms of caspase-mediated regulation of cell migration.

\section{Role of Caspase-Like Decoy Molecules}

The discovery of human CARD-only proteins that resemble the CARD domain of caspase-1, such as COP/Pseudo-ICE, 
INCA and ICEBERG, highlighted the existence of a possible mechanism for the modulation of the inflammasome complexes and the consecutive IL- $1 \beta$ levels. ${ }^{88-91}$ COP, INCA and ICEBERG all bind the caspase-1 CARD and prevent the activation of caspase- 1 and the subsequent generation of $\mathrm{IL}-1 \beta .^{88,90,91} \mathrm{COP}$, most related to the caspase-1 CARD, also binds RIP2 and activates NF- $\kappa \mathrm{B}^{88,90}$ In contrast, the more distantly related CARD-proteins INCA and ICEBERG do not display these characteristics. ${ }^{88,90}$ Interestingly, orthologs of COP, INCA and ICEBERG cannot be retrieved in the genomes of the mouse and rat. On the other hand, putative orthologs of COP and INCA, respectively, sharing 97 and $94 \%$ protein sequence identity with their human counterparts, are encoded on chromosome 9 of the chimpanzee (Lamkanfi M., unpublished data). This observation suggests that COP and INCA must have emerged by gene duplication in an ancestral mammal somewhere between 90 and 5.4 million years ago during the divergence of rodents and chimpanzees from the human lineage. Paradoxically, no ortholog for ICEBERG could be identified in the chimpanzee genome (Lamkanfi M., unpublished data), although the low sequence homology to procaspase-1 suggests an earlier phylogenetic bifurcation as compared to the other two CARD-only proteins (Figure 3). However, as this locus on chromosome 9 of the chimpanzee still contains some gaps, it remains possible that a monkey ortholog for ICEBERG will be identified in the future.

Another recent evolutionary event (100-500 thousand years ago) is the incorporation of single nucleotide polymorphisms (SNPs) in the human caspase-12 gene that lead to the production of either a CARD-only protein or a full-length caspase, although still lacking enzymatic activity. ${ }^{92,93}$ The presence of an intact QACRG motif in a rhesus monkeys and chimpanzees (Genbank accession numbers DQ644576 and XM_522166, respectively) suggests that the SNP causing the loss of enzymatic activity in the human caspase-12 gene must have arisen earlier during the bifurcation of apes and humans (around 5.4 million years ago). Some interesting parallels can be drawn between the catalytically inactive human caspase12 and the caspase-8 inhibitor c-FLIP. Both proteins resemble full-length caspases with a large $\mathrm{N}$ terminal prodomain followed by a caspase domain. Indeed, caspase-12 is a close homologue of the inflammatory caspases $-1,-4$ and -5 , while cFLIP resembles the DED-containing caspases-8 and -10 (Figure 3). However, both human caspase-12 and c-FLIP lack the conserved QACXG box that is normally present in the catalytic site of genuine caspases. Furthermore, truncated prodomain-only-expressing splice variants have been described for both caspase-like decoy molecules. ${ }^{45,92}$ These common features suggest that catalytically inactive human caspase-12 may fulfil roles reminiscent of those of c-FLIP as described above. In this respect, it is intriguing that the fulllength variant of caspase-12 is confined to specific populations of African descent and that the frequency of the fulllength allele is apparently doubled in African American individuals who suffer from sepsis. ${ }^{94}$ Furthermore, the mortality rate of patients with the read-through mutation suffering from severe sepsis is three times that of patients without the SNP. ${ }^{94}$ In line with these results, caspase-12 deficient mice have recently been shown to be resistant to peritonitis and septic shock. ${ }^{95}$ Therefore, human caspase-12

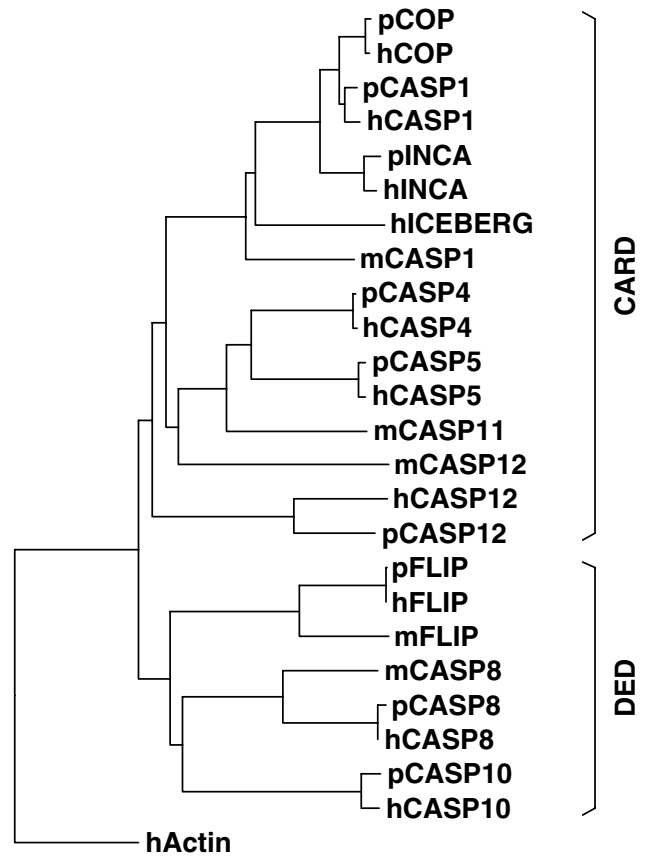

Figure 3 Phylogenetic analysis of caspase-like decoy molecules. The sequences of the short isoforms of the caspase-like decoy molecules were aligned with the prodomains of caspases-1, $-4,-5,-8,-10,-11$ and -12 using CLUSTAL X (gap weight $=20.00$; gap length weight $=0.10$ ). Trees were visualized in TreeCon. Homo sapiens (h), Mus musculus (m), (p) Pan troglodytes.

may function as a negative regulator of inflammatory signalling pathways, comparable to COP/Pseudo-ICE, INCA and ICEBERG. ${ }^{93}$ The higher incidence of severe sepsis in patients with the caspase-12 read-through mutation as compared to individuals harbouring the CARD-only variant might be attributed to a less efficient negative regulation of the caspase-1-containing inflammasome complexes due to steric hindrance of the inactive caspase domain. In this model, the short human caspase-12 isoform may block caspase-1 or -5 activation in the inflammasomes more efficiently than the fulllength isoform, reminiscent of the role of the prodomain-only isoform of C-FLIP in the DISC complex. Inhibition by the CARD-only isoform of human caspase-12 may thus render the inflammasome unable to process the pro-inflammatory cytokines pro-IL-1 $\beta$ and -18 , finally resulting in a less efficient innate immune response. Whether this or other functions are involved in caspase-12-mediated induction of sepsis needs further clarification.

\section{Conclusions and Perspectives}

The discovery that caspases also have non-apoptotic functions may change the widely accepted paradigm that caspase genes have been selected during metazoan evolution solely for their functions in programmed cell death. An interesting conceptual framework that reconciles the pleiotropic functions of caspases in an evolutionary perspective has been proposed recently. ${ }^{96}$ Therefore, caspases may have been ideally positioned to play a central role in apoptosis through the integration of their pleiotropic functions in cell cycle and 
innate immune system regulation, cell proliferation, cytokine release and cell differentiation. High levels of caspase activation achieved with or without mitochondrial amplification clearly lead to caspase-dependent apoptosis. In contrast, limited caspase activation may reveal mainly the nonapoptotic functions (proliferation, differentiation, intercellular communication through cytokine release and NF- $\kappa$ B activation). These non-apoptotic functions partly involve prodomainmediated and/or caspase activity-dependent activation of $\mathrm{NF}-\kappa \mathrm{B}$. In turn, NF- $\kappa \mathrm{B}$ could then augment the anti-apoptotic status of the cell, allowing the non-apoptotic functions of caspases to operate. A striking example of this model is provided by caspase-8 in humans and DREDD in Drosophila. By activating NF- $\kappa \mathrm{B}$, these caspases can function both as crucial mediators of apoptosis and as activators of the innate immune system. The involvement of so-called 'apoptotic' caspases in cellular differentiation and immune and inflammatory responses demonstrates that therapeutic inhibition of caspase activity to prevent cell death may have broader implications than initially conceived. On the other hand, a better understanding of caspase functions could lead to the development of novel pharmaceutical strategies to prevent inflammation or to control autoimmune diseases.

Acknowledgements. We apologize to the authors who made important contributions to the field, but have not been cited due to space limitations. We thank Amin Bredan for editorial help. This work was supported in part by the Interuniversitaire Attractiepolen V (IUAP-P5/12-120C1402), the Belgian Federation Against Cancer, the Fonds voor Wetenschappelijk Onderzoek-Vlaanderen (Grants 3G.0006.01, G.0133.05, 3G.0218.06), EC-RTD grants (QLG1-CT-1999-00739 and LSHB-CT-2005-019067), and GOA project (12050502). T. Vanden Berghe is supported by a postdoctoral grant from Ghent University (06524-BOF). N Festjens is supported by IUAP-P5/12-120C1402.

1. Lamkanfi M, Declercq W, Kalai M, Saelens X, Vandenabeele P. Alice in caspase land. A phylogenetic analysis of caspases from worm to man. Cell Death Differ 2002; 9: 358-361.

2. Shi Y. Caspase activation: revisiting the induced proximity model. Cell 2004; 117: 855-858.

3. Cain K, Bratton SB, Cohen GM. The Apaf-1 apoptosome: a large caspase-activating complex. Biochimie 2002; 84: 203-214.

4. Peter ME, Krammer PH. The CD95(APO-1/Fas) DISC and beyond. Cell Death Differ 2003; 10: 26-35.

5. Varfolomeev E, Maecker H, Sharp D, Lawrence D, Renz M, Vucic D et al. Molecular determinants of kinase pathway activation by Apo2 ligand/tumor necrosis factor-related apoptosis-inducing ligand. J Biol Chem 2005; 280: 40599-40608.

6. Tinel A, Tschopp J. The PIDDosome, a protein complex implicated in activation of caspase-2 in response to genotoxic stress. Science 2004; 304: 843-846.

7. Martinon F, Tschopp J. Inflammatory caspases: linking an intracellular innate immune system to autoinflammatory diseases. Cell 2004; 117: 561-574.

8. Imler JL, Hoffmann JA. Signaling mechanisms in the antimicrobial host defense of Drosophila. Curr Opin Microbiol 2000; 3: 16-22.

9. Leulier F, Rodriguez A, Khush RS, Abrams JM, Lemaitre B. The Drosophila caspase Dredd is required to resist gram-negative bacterial infection. EMBO Rep 2000; 1 353-358.

10. Stoven S, Ando I, Kadalayil L, Engstrom Y, Hultmark D. Activation of the Drosophila NFkappaB factor Relish by rapid endoproteolytic cleavage. EMBO Rep 2000; 1: 347-352.

11. Stoven S, Silverman N, Junell A, Hedengren-Olcott M, Erturk D, Engstrom $Y$ et al. Caspase-mediated processing of the Drosophila NF-kappaB factor relish. Proc Natl Acad Sci USA 2003; 100: 5991-5996.

12. Su $\mathrm{H}$, Bidere $\mathrm{N}$, Zheng $\mathrm{L}$, Cubre $A$, Sakai $\mathrm{K}$, Dale $\mathrm{J}$ et al. Requirement for caspase- 8 in NF-kappaB activation by antigen receptor. Science 2005; 307: 1465-1468.

13. Ruland J, Duncan GS, Wakeham A, Mak TW. Differential requirement for Malt1 in T and B cell antigen receptor signaling. Immunity 2003; 19: 749-758.

14. Salmena L, Lemmers B, Hakem A, Matysiak-Zablocki E, Murakami K, Au PY et al. Essential role for caspase 8 in T-cell homeostasis and T-cell-mediated immunity. Genes Dev 2003; 17: 883-895.
15. Yeh WC, Shahinian A, Speiser D, Kraunus J, Billia F, Wakeham A et al. Early lethality, functional NF-kappaB activation, and increased sensitivity to TNF-induced cell death in TRAF2-deficient mice. Immunity 1997; 7: 715-725.

16. Jun Jl, Chung CW, Lee HJ, Pyo JO, Lee KN, Kim NS et al. Role of FLASH in caspase-8mediated activation of NF-kappaB: dominant-negative function of FLASH mutant in NF-kappaB signaling pathway. Oncogene 2005; 24: 688-696.

17. Shall S, de Murcia G. Poly(ADP-ribose) polymerase-1: what have we learned from the deficient mouse model? Mutat Res 2000; 460: 1-15.

18. Petrilli V, Herceg Z, Hassa PO, Patel NS, Di Paola R, Cortes U et al. Noncleavable poly(ADP-ribose) polymerase-1 regulates the inflammation response in mice. $J$ Clin Invest 2004; 114: 1072-1081.

19. Hassa PO, Buerki C, Lombardi C, Imhof R, Hottiger MO. Transcriptional coactivation of nuclear factor-kappaB-dependent gene expression by p300 is regulated by poly(ADP)ribose polymerase-1. J Biol Chem 2003; 278: 45145-45153.

20. Hassa PO, Covic M, Hasan S, Imhof R, Hottiger MO. The enzymatic and DNA binding activity of PARP-1 are not required for NF-kappa B coactivator function. $J$ Biol Chem 2001; 276: 45588-45597.

21. Nakajima $H$, Nagaso $H$, Kakui $N$, Ishikawa M, Hiranuma T, Hoshiko S. Critical role of the automodification of poly(ADP-ribose) polymerase-1 in nuclear factor-kappaBdependent gene expression in primary cultured mouse glial cells. J Biol Chem 2004; 279: 42774-42786.

22. Chiarugi A, Moskowitz MA. Poly(ADP-ribose) polymerase-1 activity promotes NFkappaB-driven transcription and microglial activation: implication for neurodegenerative disorders. J Neurochem 2003; 85: 306-317.

23. Kreuz S, Siegmund D, Rumpf JJ, Samel D, Leverkus M, Janssen $O$ et al. NFkappaB activation by Fas is mediated through FADD, caspase-8, and RIP and is inhibited by FLIP. J Cell Biol 2004; 166: 369-380.

24. Lamkanfi M, D'Hondt K, Vande Walle L, Van Gurp M, Denecker G, Demeulemeester J et al. A novel caspase-2 complex containing TRAF2 and RIP1. J Biol Chem 2005; 280: 6923-6932.

25. Chaudhary PM, Eby MT, Jasmin A, Kumar A, Liu L, Hood L. Activation of the NF-kappaB pathway by caspase 8 and its homologs. Oncogene 2000; 19: 4451-4460.

26. Takahashi K, Kawai T, Kumar H, Sato S, Yonehara S, Akira S. Cutting edge: roles of caspase-8 and caspase-10 in innate immune responses to double-stranded RNA. J Immunol 2006; 176: 4520-4524.

27. Lamkanfi M, Kalai M, Saelens X, Declercq W, Vandenabeele P. Caspase-1 activates NF-kappa B independent of its enzymatic activity. J Biol Chem 2004; 279: 24785-24793.

28. Kobayashi K, Inohara N, Hernandez LD, Galan JE, Nunez G, Janeway CA et al. RICK/ Rip2/CARDIAK mediates signalling for receptors of the innate and adaptive immune systems. Nature 2002; 416: 194-199.

29. Sarkar A, Duncan M, Hart J, Hertlein E, Guttridge DC, Wewers MD. ASC directs NF-kappaB activation by regulating receptor interacting protein-2 (RIP2) caspase-1 interactions. J Immunol 2006; 176: 4979-4986.

30. Hur GM, Lewis J, Yang Q, Lin Y, Nakano H, Nedospasov S et al. The death domain kinase RIP has an essential role in DNA damage-induced NF-kappa B activation. Genes Dev 2003; 17: 873-882.

31. Janssens S, Tinel A, Lippens S, Tschopp J. PIDD mediates NF-kappaB activation in response to DNA damage. Cell 2005; 123: 1079-1092.

32. Zhivotovsky B, Orrenius S. Caspase-2 function in response to DNA damage. Biochem Biophys Res Commun 2005; 331: 859-867.

33. Bergeron L, Perez Gl, Macdonald G, Shi L, Sun Y, Jurisicova A et al. Defects in regulation of apoptosis in caspase-2-deficient mice. Genes Dev 1998; 12: 1304-1314.

34. Chang DW, Xing Z, Pan Y, Algeciras-Schimnich A, Barnhart BC, Yaish-Ohad S et al. cFLIP(L) is a dual function regulator for caspase-8 activation and CD95-mediated apoptosis. EMBO J 2002; 21: 3704-3714.

35. Krueger A, Schmitz I, Baumann S, Krammer PH, Kirchhoff S. Cellular FLICE-inhibitory protein splice variants inhibit different steps of caspase-8 activation at the CD95 deathinducing signaling complex. J Biol Chem 2001; 276: 20633-20640.

36. Scaffidi C, Schmitz I, Krammer PH, Peter ME. The role of c-FLIP in modulation of CD95induced apoptosis. J Biol Chem 1999; 274: 1541-1548.

37. Kataoka T, Tschopp J. N-terminal fragment of $c-F L I P(L)$ processed by caspase 8 specifically interacts with TRAF2 and induces activation of the NF-kappaB signaling pathway. Mol Cell Biol 2004; 24: 2627-2636.

38. Golks A, Brenner D, Krammer PH, Lavrik IN. The c-FLIP-NH2 terminus (p22-FLIP) induces NF-\{kappa\}B activation. J Exp Med 2006; 203: 1295-1305.

39. Chun HJ, Zheng L, Ahmad M, Wang J, Speirs CK, Siegel RM et al. Pleiotropic defects in lymphocyte activation caused by caspase-8 mutations lead to human immunodeficiency. Nature 2002; 419: 395-399

40. Beisner DR, Ch'en IL, Kolla RV, Hoffmann A, Hedrick SM. Cutting edge: innate immunity conferred by B cells is regulated by caspase-8. J Immunol 2005; 175: 3469-3473.

41. Salmena L, Hakem R. Caspase-8 deficiency in T cells leads to a lethal lymphoinfiltrative immune disorder. J Exp Med 2005; 202: 727-732.

42. Wang J, Zheng L, Lobito A, Chan FK, Dale J, Sneller M et al. Inherited human Caspase 10 mutations underlie defective lymphocyte and dendritic cell apoptosis in autoimmune lymphoproliferative syndrome type II. Cell 1999; 98: 47-58. 
43. Gronbaek K, Dalby T, Zeuthen J, Ralfkiaer E, Guidberg P. The V410I (G1228A) variant of the caspase-10 gene is a common polymorphism of the Danish population. Blood 2000; 95: 2184-2185.

44. Varfolomeev EE, Schuchmann M, Luria V, Chiannilkulchai N, Beckmann JS, Mett IL et al. Targeted disruption of the mouse Caspase 8 gene ablates cell death induction by the TNF receptors, Fas/Ap01, and DR3 and is lethal prenatally. Immunity 1998; 9: 267-276.

45. Tschopp J, Irmler M, Thome M. Inhibition of fas death signals by FLIPs. Curr Opin Immunol 1998; 10: 552-558.

46. Micheau O, Thome M, Schneider P, Holler N, Tschopp J, Nicholson DW et al. The long form of FLIP is an activator of caspase-8 at the Fas death-inducing signaling complex. J Biol Chem 2002; 277: 45162-45171.

47. Boatright KM, Deis C, Denault JB, Sutherlin DP, Salvesen GS. Activation of caspases-8 and -10 by FLIP(L). Biochem J 2004; 382: 651-657.

48. Dohrman A, Kataoka T, Cuenin S, Russell JQ, Tschopp J, Budd RC. Cellular FLIP (long form) regulates $\mathrm{CD} 8+\mathrm{T}$ cell activation through caspase-8-dependent NF-kappa B activation. J Immunol 2005; 174: 5270-5278.

49. Irmler M, Thome M, Hahne M, Schneider P, Hofmann K, Steiner V et al. Inhibition of death receptor signals by cellular FLIP. Nature 1997; 388: 190-195.

50. Ekert PG, Silke J, Vaux DL. Caspase inhibitors. Cell Death Differ 1999; 6: 1081-1086.

51. Chaudhary PM, Jasmin A, Eby MT, Hood L. Modulation of the NF-kappa B pathway by virally encoded death effector domains-containing proteins. Oncogene 1999; 18 $5738-5746$.

52. Chugh P, Matta H, Schamus S, Zachariah S, Kumar A, Richardson JA et al. Constitutive NF-kappaB activation, normal Fas-induced apoptosis, and increased incidence of lymphoma in human herpes virus $8 \mathrm{~K} 13$ transgenic mice. Proc Natl Acad Sci USA 2005; 102: $12885-12890$

53. Lens SM, Kataoka T, Fortner KA, Tinel A, Ferrero I, MacDonald RH et al. The caspase 8 inhibitor $\mathrm{c}-\mathrm{FLIP}(\mathrm{L})$ modulates T-cell receptor-induced proliferation but not activationinduced cell death of lymphocytes. Mol Cell Biol 2002; 22: 5419-5433.

54. Zhang N, He YW. An essential role for c-FLIP in the efficient development of mature lymphocytes. J Exp Med 2005; 202: 395-404

55. Smith KG, Strasser A, Vaux DL. CrmA expression in T lymphocytes of transgenic mice inhibits CD95 (Fas/APO-1)-transduced apoptosis, but does not cause lymphadenopathy or autoimmune disease. EMBO J 1996; 15: 5167-5176.

56. De Botton S, Sabri S, Daugas E, Zermati Y, Guidotti JE, Hermine $O$ et al. Platele formation is the consequence of caspase activation within megakaryocytes. Blood 2002; 100: 1310-1317.

57. Yan XX, Naibauer J, Woo CC, Dashtipour K, Ribak CE, Leon M. Expression of active caspase-3 in mitotic and postmitotic cells of the rat forebrain. J Comp Neurol 2001; 433 4-22.

58. Frost V, Delikat S, Al-Mehairi S, Sinclair AJ. Regulation of p27KIP1 in Epstein-Barr virusimmortalized lymphoblastoid cell lines involves non-apoptotic caspase cleavage. J Gen Virol 2001; 82: 3057-3066.

59. Woo M, Hakem R, Furlonger C, Hakem A, Duncan GS, Sasaki T et al. Caspase-3 regulates cell cycle in B cells: a consequence of substrate specificity. Nat Immunol 2003; 4: 1016-1022.

60. Waga S, Hannon GJ, Beach D, Stillman B. The p21 inhibitor of cyclin-dependent kinases controls DNA replication by interaction with PCNA. Nature 1994; 369: 574-578.

61. Gervais JL, Seth $\mathrm{P}$, Zhang H. Cleavage of CDK inhibitor p21(Cip1/Waf1) by caspases is an early event during DNA damage-induced apoptosis. J Biol Chem 1998; 273: $19207-$ 19212.

62. Wu W, Misra RS, Russell JQ, Flavell RA, Rincon M, Budd RC. Proteolytic regulation of nuclear factor of activated T (NFAT) c2 cells and NFAT activity by caspase-3. J Biol Chem 2006; 281: 10682-10690.

63. Huh JR, Guo M, Hay BA. Compensatory proliferation induced by cell death in the Drosophila wing disc requires activity of the apical cell death caspase Dronc in a nonapoptotic role. Curr Biol 2004; 14: 1262-1266.

64. James AA, Bryant PJ. A quantitative study of cell death and mitotic inhibition in gammairradiated imaginal wing discs of Drosophila melanogaster. Radiat Res 1981; 87: 552-564.

65. Golpon HA, Fadok VA, Taraseviciene-Stewart L, Scerbavicius R, Sauer C, Welte T et al. Life after corpse engulfment: phagocytosis of apoptotic cells leads to VEGF secretion and cell growth. FASEB J 2004; 18: 1716-1718.

66. Zandy AJ, Lakhani S, Zheng T, Flavell RA, Bassnett S. Role of the executioner caspases during lens development. J Biol Chem 2005; 280: 30263-30272.

67. Dahm R. Lens fibre cell differentiation - A link with apoptosis? Ophthalmic Res 1999; 31 163-183.

68. Zermati Y, Garrido C, Amsellem S, Fishelson S, Bouscary D, Valensi F et al. Caspase activation is required for terminal erythroid differentiation. J Exp Med 2001; 193: 247-254.

69. Shcherbina A, Remold-O'Donnell E. Role of caspase in a subset of human platelet activation responses. Blood 1999; 93: 4222-4231.

70. Lippens S, Kockx M, Knaapen M, Mortier L, Polakowska R, Verheyen A et al. Epiderma differentiation does not involve the pro-apoptotic executioner caspases, but is associated with caspase-14 induction and processing. Cell Death Differ 2000; 7: 1218-1224.

71. Okuyama R, Nguyen BC, Talora C, Ogawa E, Tommasi di Vignano A, Lioumi M et al. High commitment of embryonic keratinocytes to terminal differentiation through a Notch1caspase 3 regulatory mechanism. Dev Cell 2004; 6: 551-562.
72. Sordet O, Rebe C, Plenchette S, Zermati Y, Hermine O, Vainchenker W et al. Specific involvement of caspases in the differentiation of monocytes into macrophages. Blood 2002; 100: 4446-4453.

73. Kang TB, Ben-Moshe T, Varfolomeev EE, Pewzner-Jung Y, Yogev N, Jurewicz A et al. Caspase-8 serves both apoptotic and nonapoptotic roles. J Immunol 2004 173: 2976-2984.

74. Black S, Kadyrov M, Kaufmann P, Ugele B, Emans N, Huppertz B. Syncytial fusion of human trophoblast depends on caspase 8. Cell Death Differ 2004; 11: 90-98.

75. Fernando P, Kelly JF, Balazsi K, Slack RS, Megeney LA. Caspase 3 activity is required for skeletal muscle differentiation. Proc Natl Acad Sci USA 2002; 99: 11025-11030.

76. Miura M, Chen XD, Allen MR, Bi Y, Gronthos S, Seo BM et al. A crucial role of caspase-3 in osteogenic differentiation of bone marrow stromal stem cells. J Clin Invest 2004; 114 1704-1713.

77. Fernando $P$, Brunette $S$, Megeney LA. Neural stem cell differentiation is dependent upon endogenous caspase 3 activity. FASEB J 2005; 19: 1671-1673.

78. Kuranaga E, Kanuka H, Tonoki A, Takemoto K, Tomioka T, Kobayashi M et al. Drosophila IKK-related kinase regulates nonapoptotic function of caspases via degradation of IAPs. Cell 2006; 126: 583-596.

79. Santambrogio L, Potolicchio I, Fessler SP, Wong SH, Raposo G, Strominger JL. Involvement of caspase-cleaved and intact adaptor protein 1 complex in endosomal remodeling in maturing dendritic cells. Nat Immunol 2005; 6: 1020-1028.

80. Hu S, Yang X. dFADD, a novel death domain-containing adapter protein for the Drosophila caspase DREDD. J Biol Chem 2000; 275: 30761-30764.

81. Arama E, Agapite J, Steller H. Caspase activity and a specific cytochrome $C$ are required for sperm differentiation in Drosophila. Dev Cell 2003; 4: 687-697.

82. Cooper TG, Yeung $\mathrm{CH}$. Acquisition of volume regulatory response of sperm upon maturation in the epididymis and the role of the cytoplasmic droplet. Microsc Res Tech 2003; 61: 28-38.

83. Print CG, Loveland $\mathrm{KL}$. Germ cell suicide: new insights into apoptosis during spermatogenesis. Bioessays 2000; 22: 423-430.

84. Okamoto $\mathrm{H}$, Shiraishi $\mathrm{H}$, Yoshida $\mathrm{H}$. Histological analyses of normally grown, fertile Apaf1-deficient mice. Cell Death Differ 2006; 13: 668-671.

85. Geisbrecht ER, Montell DJ. A role for Drosophila IAP1-mediated caspase inhibition in Rac-dependent cell migration. Cell 2004; 118: 111-125.

86. Fischer U, Janicke RU, Schulze-Osthoff K. Many cuts to ruin: a comprehensive update of caspase substrates. Cell Death Differ 2003; 10: 76-100.

87. Helfer B, Boswell BC, Finlay D, Cipres A, Vuori K, Bong Kang T et al. Caspase-8 promotes cell motility and calpain activity under nonapoptotic conditions. Cancer Res 2006; 66: 4273-4278.

88. Lamkanfi M, Denecker G, Kalai M, D'Hondt K, Meeus A, Declercq W et al. INCA, a novel human caspase recruitment domain protein that inhibits interleukin-1beta generation. J Biol Chem 2004; 279: 51729-51738.

89. Humke EW, Shriver SK, Starovasnik MA, Fairbrother WJ, Dixit VM. ICEBERG: a nove inhibitor of interleukin-1beta generation. Cell 2000; 103: 99-111.

90. Druilhe A, Srinivasula SM, Razmara M, Ahmad M, Alnemri ES. Regulation of IL-1beta generation by Pseudo-ICE and ICEBERG, two dominant negative caspase recruitment domain proteins. Cell Death Differ 2001; 8: 649-657.

91. Lee SH, Stehlik C, Reed JC. Cop, a caspase recruitment domain-containing protein and inhibitor of caspase-1 activation processing. J Biol Chem 2001; 276: 34495-34500.

92. Fischer H, Koenig U, Eckhart L, Tschachler E. Human caspase 12 has acquired deleterious mutations. Biochem Biophys Res Commun 2002; 293: 722-726.

93. Lamkanfi M, Kalai M, Vandenabeele P. Caspase-12: an overview. Cell Death Differ 2004 11: 365-368.

94. Saleh M, Vaillancourt JP, Graham RK, Huyck M, Srinivasula SM, Alnemri ES et al. Differential modulation of endotoxin responsiveness by human caspase-12 polymorphisms. Nature 2004; 429: 75-79.

95. Saleh M, Mathison JC, Wolinski MK, Bensinger SJ, Fitzgerald P, Droin N et al. Enhanced bacterial clearance and sepsis resistance in caspase-12-deficient mice. Nature 2006 440: $1064-1068$

96. Ameisen JC. On the origin, evolution, and nature of programmed cell death: a timeline of four billion years. Cell Death Differ 2002; 9: 367-393.

97. Ghayur T, Banerjee S, Hugunin M, Butler D, Herzog L, Carter A et al. Caspase-1 processes IFN-gamma-inducing factor and regulates LPS-induced IFN-gamma production. Nature 1997; 386: 619-623.

98. Li P, Allen H, Banerjee S, Franklin S, Herzog L, Johnston C et al. Mice deficient in IL-1 beta-converting enzyme are defective in production of mature IL-1 beta and resistant to endotoxic shock. Cell 1995; 80: 401-411.

99. Franchi L, Amer A, Body-Malapel M, Kanneganti TD, Ozoren N, Jagirdar R et al. Cytosolic flagellin requires Ipaf for activation of caspase-1 and interleukin 1beta in salmonellainfected macrophages. Nat Immunol 2006; 7: 576-582.

100. Mariathasan S, Weiss DS, Dixit VM, Monack DM. Innate immunity against Francisella tularensis is dependent on the ASC/caspase-1 axis. J Exp Med 2005; 202: 1043-1049.

101. Martinon F, Burns K, Tschopp J. The inflammasome: a molecular platform triggering activation of inflammatory caspases and processing of proll-beta. Mol Cell 2002: 10 : 417-426.

102. Wang S, Miura M, Jung YK, Zhu H, Li E, Yuan J. Murine caspase-11, an ICE-interacting protease, is essential for the activation of ICE. Cell 1998; 92: 501-509. 
103. Eckhart L, Declercq W, Ban J, Rendl M, Lengauer B, Mayer C et al. Terminal differentiation of human keratinocytes and stratum corneum formation is associated with caspase-14 activation. J Invest Dermatol 2000; 115: 1148-1151.

104. Alam A, Cohen LY, Aouad S, Sekaly RP. Early activation of caspases during T lymphocyte stimulation results in selective substrate cleavage in nonapoptotic cells. J Exp Med 1999; 190: 1879-1890.

105. Eymin B, Sordet O, Droin N, Munsch B, Haugg M, Van de Craen M et al. Caspaseinduced proteolysis of the cyclin-dependent kinase inhibitor p27Kip1 mediates its antiapoptotic activity. Oncogene 1999; 18: 4839-4847.

106. Frost V, Al-Mehairi S, Sinclair AJ. Exploitation of a non-apoptotic caspase to regulate the abundance of the cdkl p27(KIP1) in transformed lymphoid cells. Oncogene 2001; 20: 2737-2748.
107. Olson NE, Graves JD, Shu GL, Ryan EJ, Clark EA. Caspase activity is required for stimulated B lymphocytes to enter the cell cycle. J Immunol 2003; 170: 6065-6072.

108. Cathelin S, Rebe C, Haddaoui L, Simioni N, Verdier F, Fontenay $M$ et al. Identification of proteins cleaved downstream of caspase activation in monocytes undergoing macrophage differentiation. I Biol Chem 2006; 281: 17779-17788.

109. Barnoy S, Kosower NS. Caspase-1-induced calpastatin degradation in myoblast differentiation and fusion: cross-talk between the caspase and calpain systems. FEBS Lett 2003; 546: 213-217.

110. Ishizaki Y, Jacobson MD, Raff MC. A role for caspases in lens fiber differentiation. J Cell Biol 1998; 140: 153-158. 